JOSEPH OLUCHUKWU WOGU,

Department of Mass Communication, University of Nigeria (Nsukka, Nigeria)

e-mail: Joseph.Wogu@unn.edu.ng, ORCID0000-0002-2384-1510

\title{
REACHING THE UNHEARD VOICES AND HINTERLANDS IN THE DIGITAL ERA: AN ASSESSMENT OF THE RE-ENGINEERING OF NEWSGATHERING IN AFRICA
}

\begin{abstract}
Historically, Africa is known to be backward in adoption of technology. History has it that Africa trailed behind in the use of new technology for newsgathering. Africa is the 2nd largest continent after Asia with over $60 \%$ of its population living widely dispersed in hinterlands whose insecure terrains, inaccessibility, and distance from cities, make it impossible for journalist and media broadcasts to cover their socio-economic, cultural and political activities. In addition to these factors, scarcity of journalists, costs and conflicts, inability of media industries to train and/or recruit enough journalists, government indifference and pro-urban communication policy made newsgathering in African hinterlands almost impossible. However, the evolution and reign of Internet-based technologies, which enable citizens to contribute to news-making, and information gathering and exchange became a solution. Nevertheless, it is confronted with pro-urban middle class relevance due to epileptic power, poor network, low level of education and technology skills, and lack of formal framework for newsgathering in the hinterlands. This paper, therefore, explores the dynamics of newsgathering in the technologically-driven internet era, with a view to identifying inherent limitations in African hinterlands, and therefrom offers profitable recommendations. Geographically, the study considers African rural communities. Thematically, the paper is an investigation into the acquisition and use new information technologies particularly phones with internet facilities to generate and circulate news from African hinterlands, factors hindering the practice and possible ways of enhancing it. Periodically, the study covers the 21st century i.e. 2000 to date, which has witnessed ICTs massive penetration of the hinterlands and their use as primary medium of communication. In exploring the digitalisation of communication in rural Africa where majority of the population lives without regular or formal connection to organs and channels of governance and events in the entire world, this paper is significant to the extent that it assess and exposes the challenges modernisation is facing in trying to provide solution to the scenario. It explores areas of investments in media and communication in rural Africa, and attempts to provide viable alternatives to the problems hindering internet-mediated-technologies approach to newsgathering in rural Africa. It provides approaches to the democratisation of newsgathering and circulation, which opens up rural Africa to the global community and for participation in e-governance, global dialogue and discussions in every aspect of human development, rights and politics. This paper adopted logical inquiry, survey of literature and expost facto methods of data gathering. Central to these methods, extensive literature review was primarily adopted as data gathering processes. This is because of the wealth of literature, debates and criticism available on the new media, newsgathering, and the African experience particularly the hinterlands. This will explicate new areas of investments in communication technologies and provide valid framework for newsgathering across Africa, which will inevitably advance globalisation into and enhance development in African hinterlands.
\end{abstract}

Key words: Newsgathering; Hinterlands; Africa; Internet-based technologies; Globalisation; development.

\section{INTRODUCTION}

It is substantiated in the literature that technological revolution and modernisation, which led to media globalisation and liberalization, changed the communication landscape in Africa since the beginning of the $21^{\text {st }}$ century (Hydén et al., 2002; Njogu and Middleton 2009; Wasserman, 2011). The era has being characterised by upsurge and establishment of public and private digital media institutions such as online newspapers and magazines, radio and TV stations, and cable networks. Undisputedly, this facilitates national and transnational flows of information or news and entertainment (Böhme, 2013). Equally, it led to the emergence of a series of new and more inde- pendent media actors in the areas of newspaper, radio, and TV news production/circulation (deWitte, 2011; Saul and Austen, 2010; Englert and Moreto, 2010; Ugwuanyi, Gever, \& Olijo, 2019). This is accelerated and sustained by increasing availability and appropriate new information and communication technologies (ICTs).

The scenario tends to heal major problems confronting media and communication in Africa. The continent is characteristically the world's largest and most populous only next to Asia. Over $60 \%$ of this population are living in widely dispersed hinterlands whose terrains are mostly inaccessibility and very far away from the cities and the seat of government. Their terrains are infested with hostilities/ 
conflicts, banditry, under-development and poor/no network connection that renders them incommunicado. They are not heard, no information about their socio-economic, cultural and political activities; and they do not hear either from their government, the cities and the global communities. Researchers attributed this to scarcity of journalists that would have covered those hinterlands in search of news, the costs of sending journalists, conflicts and the risks of death and kidnap, inability of media industries to train journalists (Cloudry \& Derher, 2007; Hess, 2013; Wogu; Ezeah, Gever, \& Ugwuanyi, 2019), government indifference to rural plights, and pro-urban communication policy of most governments in African.

In the face of these problems, Africans' privileged access to new media technologies and the digitalisation of communication in the $21^{\text {st }}$ century became mediating factors between the dispersed audiences in the hinterlands, spaces and communication hazards (see Lewis \& Mosse, 2006; Freedman \& Shafer, 2012). This mediation, which is a synthesis of media liberalization in various domains, created new spaces for individuals, locals, and unhindered participation in information generation and circulation, its creation and participation in processes of governance (Allan, 2009; Shipley, 2009). People became consumers and producers of information as well as their circulators. Without formal appointment, remuneration, and or harassment by government authorities, individually they engage themselves in gathering information about sociocultural, political, and economic activities in the hinterlands together with their developmental needs, and circulate same through ICT mediated communication channels such as the internet and/or social networking sites (Agbodike, 1992). Example of such networking through which text messages, photos, audio, video and information are generally and increasingly exchanged include platforms like Twitter, Facebook, LinkedIn, Online Communities, YouTube, LinkedIn, Pinterest, Google Plus, Quantcast, Instagram, VK, Flickr, Vine Rank, Meetup, Tagged, Ask.fm, and ClassMates etc (Dominick, 2013; Tomno, 2012). Either for disparaging the government or exposing what the government is doing (good or bad), or promoting rural ingenuity and culture, and economic activities, the dwellers circulate rural information on these platforms with delight.

This incites new sensational effects, lays the background for and facilitates a new practice or form of newsgathering, which blurs the existing boundaries between censored/official practices and popular/pro-liberal practices (Meyer, 2010; Förster, 2002). Essentially, it has become a good alternative to perceived doctored news gathered or nationally produced content by journalists in the employ of government controlled and/or owned media institutions (see Spitulnik, 2002). Such nationally produced contents have hidden agendas, advances political interests, and are couched to circumvent legal sanctions. In the available alternative, the supressed and unheard voices of the rural and uneducated people are heard; events, problems and development in the rural areas become public knowledge, while external news and information are made available to the rural dwellers. It enables the rural dwellers to engage in interactive dialogue on virtually all socio-economic, political/governance, religious, and cultural issues that characterise the new media regime (Joseph, 2013). On their part, national and international media institutions do not solicit for information concerning rural events neither does they need to recruit, train and send their journalists into the hinterlands to gather news or information. They only need to create websites and links through which information can be received from rural inhabitants or engage internet experts to surf for rural news if they choose to. On the part of rural dwellers, they need only Smart or Android phones, active batteries, the skill on how to use them, good network connection, data, and security against robbery.

Nevertheless, this use of internet-mediated-technologies such as Smart or Android phones, satellite devices, SW (short wave) and FM transmitters, or internet streams (Larkin, 2004) by dwellers in African hinterlands to gather and circulate information has being greatly and negatively affected by its pro-urban middle class relevance and use, poor or epileptic power supply, poor or no network connection, low level of education and technology skills, and lack of formal framework for newsgathering in the hinterlands. Consequently, newsgathering in rural Africa has continued to be in the hands of conventional journalists, who visit and engage rural areas only during major calamities and festivals, though in a distorted form with excessive progovernment bias. Effective newsgathering in the rural area requires that the reporter should live with, most times be direct, unobtrusive and participant observer, and understand the rural people and the dynamics of their culture, interactions, and environmental peculiarities (Brooks et al, 1980; Dennis and Ismach, 1981; Nwosu, 1986). Such must display unalloyed commitment for development and better living conditions.

Considering the fact that over $84 \%$ of Africans use Mobile phones that have internet inclusiveness (Gicheru, 2014), the rising tides of social networking and internet-mediatedtechnologies approach to newsgathering with multiple advantages, and the prevalence of orthodox or conventional approach to newsgathering, which usually produces national content with its deformities, this paper explores the dynamics of internet-mediated-technologies approach with a view identify its limitations in rural Africa. It is therefore the goal of this paper to find answers to the following research questions:

1. Are majority of African rural dwellers Internet users, and do they generate and circulate information/news through the internet platforms?

2. Has the emergence of new information technologies affected the process, the quantity and quality of news gathering in rural African communities?

3. What are the major problems hindering the effective adoption or application of internet-mediated-technologies approach to newsgathering in rural Africa?

\section{REVIEW OF EXTANT LITERATURE}

We are currently in the digital media era where information and communication technologies are playing critical roles. The role of Information and Communication Technologies (ICTs) in generating and disseminating information known as new media has being extensively discussed in the literature (See Wirsiy and Shafack 2002 in Bappah, 2010; Pavlik, 2001; Deuze, 2008). One of the essential part of the digital media era is social media. Social media is defined as "a group of Internet-based applications that build on the ideological and technological foundations of Web 2.0 and that allow the creation and exchange of User Generated Content" (Kaplan \& Haenlein, 2010: 61). It is a new form of media designed to enhance mass communication, the formation of social ties and social interactions among geographically dispersed population, which is driven by new information and communication technologies (Donath, 2004; Harrison and Barthel, 2009). This form of media is "...principally about participating rather than about passively receiving information" (Tapscott and Williams, 2006: 37). It is a medium of communication that is characteristically participatory, open, interactive, communal, and easy connectivity in nature 
(Hermida, 2011). It allows for the free creation and accessible exchange of user-generated contents (Kaplan and Haenlein, 2010; Hardey, 2007), and for continual sharing of contents under status updates, links, photos, and videos, news, information, and comment on current realities (Gillmor, 2006; Goldfain \& Van der Merwe, 2006; De Vries, 2008; Holcomb et al., 2011).

Consequently, social media has become an irresistible source of news and information for journalists and media institutions because it allows for consumer-generated contents (Pew Research, 2010; Reece, 2009b; Moses, 2009). The media is focused on the logic of "sharing" - i.e. exchange of information, comments/views, messages, photos and videos (Gerlitz, 2011; Boyd, Ellison, 2007). Thus, it has been effectively used as instrument for propagating and covering socio-cultural, development and political activities/events by individuals, groups, public and private institutions (Kaid, 2009; Veglis, 2012). Specifically, social media is dominantly used for sharing information/ reporting news, seeking information or gathering news, and for the development and sustenance of friendly relations (Bonds-Raacke and Raacke, 2010; Veglis, 2012).

\section{New Media and Newsgathering}

Different social media sites such as Myspace, Linkedln, Tumblr, Spotify, Foursquare, Facebook, WhatsApp, Flicker, and Twitter etc. have being devoted to gathering or seeking and disseminating information since the beginning of the $21^{\text {st }}$ century across Africa (Hendricks, 2013). This enables journalists to generate information or news from widely dispersed and long distant areas, and to circulate information also to millions of people easily (Joseph, 2013). Their users post stories and events from their locations (Drew, 2013; Liz Heron, 2014).

Clearly, the new media has restructured journalism, the manner of newsgathering and distribution, their consumers and modes of consumption (Lee-Wright, 2010; Kovac \& Rosenthal, 2001). It allows the people or users to pick and choose news at their own pace and time whereas information flow is regulated in the mainstream media through censorship. Due to technology, newsgathering and dissemination is driven by non-professional journalists who are disinfested with corporate interests (Adams, 2006). Their number outweighs that of professional journalists while unlike the professionals, they engage in newsgathering and dissemination without any form of corporate empowerment or payment (Flew, 2009). Many call this citizen journalism (Adams, 2006).

In citizen journalism, people formerly known as 'the audience' or media consumers now use the tools they have in their possession such as phone to gather news and inform others about it through networked platforms (Picard, 2014; Rosen, 2008). Although professional journalists are critical of their role or participation (Heinonen, 2011; O'Sullivan, 2005) due to lack of required skills and "software familiarity" (Brannon, 2008; Matsiola, 2008; Spyridou, 2009), and perceived undermining of journalists' authority and ideals (Chadwick and Collister, 2014; Hermida, 2012; Quinn and Quinn-Allan, 2005), they become active participator in the construction of news and its gathering (Newman, Dutton, and Blank, 2012; Siapera, Papadopoulos, and Archontakis, 2014).

Instead of investigating the place of new media in newsgathering in African hinterlands, most scholars concentrated on its use by professional journalists who are urban based and elitist in nature. For instance, Mchakulu (2007) investigated the impact of new technologies on the professional practices of Malawian journalists, their use of new technologies and its impact. He observed that in spite of financial limitations, the use of new technologies improved and mobilised Malawian journalists' professional practice. Similarly, Mudhai (2004) and Kupe (2003) noted that the interactive nature of the new technologies enables journalists in Africa to move closer to engaging with news consumers, and alters news production processes.

Other scholars focus on the generation of news content by citizens using mobile phone. Verclas \& Mechael (2008) observed that individuals with mobile phones and other media tools are able to capture 'news' in real time more than professional journalists; and normally circulate such immediately using text messaging function (Moyo, 2009). In this sense, it is posited that mobile phone facilitates or allows citizens to participate in the process of newsgathering and dissemination (Verclas \& Mechael, 2008). In essence, it has turned journalists into individualised and unprofessional people. Many scholars like Foss (2008) and Goldfain and van der Merwe (2006) have criticised this development because there is no quality control, and such individuals are not under any professional obligation to honour the ethics of journalism such as accuracy and balance.

Generally, different scholars have demonstrated the effectiveness of new technologies in bolstering newsgathering (Johnston and Forde, 2011; Hultin and Skog, 2011; Brautovic, 2009) although it tend to eliminate journalists exclusivity to assignment materials and interactive learning opportunity for younger journalists. Thus, many scholars, having seen the advantages and roles of citizens' journalism in connecting the hinterlands to the cities and the world in general are engaging themselves with inquiries and analysis of factors that influence or moderate it. See also Ettema et al. (1997), McNair (1998), Lowrey (2006), Obieng-Quaidoo (1986), McNair (1998), Esipisu and Kariithi (2007).

Castells (2001: 247) identified the peculiar factors that influence the application of new technologies in citizens' journalism as "the...difficulty for people without sufficient education, knowledge and skills to appropriate the \{technologies\} for their own interests and values." Complementing these factors, the disproportionate distribution of electricity; total absence of energy supply particularly in the hinterlands, poor and unreliable telecommunications infrastructure; connectivity challenges and content issues, undermine the application of new technologies in newsgathering by residents in African hinterlands. It can be observed that the literature is limited in its exploration of the impact of digitalisation, satellite system, and the emergence of alternative sources of energy such as solar and use of electric generators on these problems. This paper explores these areas.

Framework of Analysis

This study was anchored on the theory of mediamorphosis. The critical postulation of the theory is that media and indeed journalism has undergone several changes in scope and performance. The theory is largely attributed to Kurt Blaukopt who is considered as the founding protagonist of the theory. Kurt used the theory to explain the changes that have taken place in the media as a result of advancements in information and communication technologies (Blaukopt, 1992; Sperlich, 2006). Roger Fidler made use of the theory to explain changes that have taken place in communication as a result of the digital media era. (Fidler, 1997). According to Fidler (1997), the theory has six fundamental principles, namely: These principles are:

a. Coevolution and coexistence: This places attention on the need for harmony between the old and the new media options. 
b. Metamorphosis: This implies that the new media came out from the old to remain independent.

c. Propagation: The new media reveals the essential features of the old media.

d. Survival instinct: This entails that there is the need for both the new and the old media to get use to changes so as to remain relevant.

e. Opportunity and Need: This reveals that the new media is conditioned to meet the need of people.

f. Delayed adoption: The level at which people will accept and make use of new media platforms may not be fast.

Considering these principles, the theory enables the paper to seek for and explain expected delay or problems associated with the adoption of ICTs in newsgathering, and to explore how the new media is serving the current needs of people living in rural Africa, and the emerging new trends therefrom. These make the theory applicable and relevant.

\section{METHODOLOGY}

This paper adopted logical inquiry, survey of literature and expost facto methods of data gathering. Central to these methods, extensive literature review was primarily adopted as data gathering processes. This is because of the wealth of literature, debates and criticism available on the new media, newsgathering, and the African experience particularly the hinterlands.

\section{Methods of Data Collection}

The methods adopted for gathering data used library documents (both private and public) wherein published materials such as books, journals, workshop and lecture papers, and government publications are preserved. The research equally explored available and relevant works and documents found online in the internet at different websites.

\section{Method of Data Analysis}

Trend analysis was adopted for purposes of inference. The method here was to determine which applicable variables and their indices will be analysed; thereafter their empirical indices were determined. In this case, these include ICTs, newsgathering, news circulation. Once these variables and their empirical indices were identified and/ or selected, their relationships and causative interactions were examined and determined, inferences were reached or drawn. Based on the findings, the researcher then attempted to predict the direction of newsgathering using the internet-mediated-technologies approach and the requirements thereof for its effectiveness.

\section{DATAANALYSIS AND FINDINGS}

Are majority of African rural dwellers internet users, and do they generate and circulate information/news through internet platforms?

ICTs revolution and the Western drive to consolidate its hold of African market have led to massive mobile phone penetration into the continent (Vodafone, 2005). Consequently, Africa has been experiencing an incredible increase or boom in the number mobile phone users since the beginning of the $21^{\text {st }}$ century. In 2000 , there were fewer than 3.6 million mobile phone users in the continent but today Africa is at the centre of a mobile revolution with over 900 million phone users. This growth can be explained by the fact that mobile phone emerged as the only available, accessible, low-cost, gender and status free medium of communication. This was enhanced by the huge economic potential that mobile phones carry particularly in the socioeconomically backward hinterlands of Africa. It was found useful in all aspect of people's lives and activities such as farming, information transmission, education, health and natural crises etc particularly in the isolated rural areas.

However, the nature of activities and degree to which people use these mobile phones for depend on their ingenuity and the type or capacity of the phones. Certain type of phones can only transmit voice calls and send text messages, while others perform additional functions of taking and transmitting picture, recording and transmitting videos, connecting to satellites and cables, etc. The later type is generally known as Smartphones/Android phones. It is only through this type of phone that people are connected with the world through the internet.

According to data published by Internet World Status, ITU, Facebook, and other trustworthy information sources, the total number of African internet users as at September 2019 stands at $522,809,480$. This represents $43.6 \%$ of the population. Details and the countries of origin of the internet subscribers are hereby presented in table 1 as follows.

It is considerably impossible to find out the number and percentage of the 522,809,480 African internet Users as at $30^{\text {th }}$ June 2019 that are resident in the hinterlands, and their use of phones to generate and disseminate news/information. However, evidences or experiences during two categorical historic internet driven crises in Africa (i.e. the Arab Spring and the Kenya election) and other national bound experiences like Zimbabwe's general elections, and the Nigerian 2011 and 2015 general elections, equip us to make valid inference here.

During the 2011 Arab Spring, opposition to authoritarian rule was a collectively consistent action across the North African region. Social movement leaders employed the instrumentality of the new media to connect with leaders of democratization movements and civil liberty organisations in each of the countries involved and other countries outside the region particularly Europe and America. Citizens of their countries, irrespective of their locations are also connected with them and with themselves via the new media. Thus, the new media was a necessary and sometimes sufficient cause of the Arab Spring or democratization struggle that took place in the region.

The organising activists, which may belong to the United States' trained and sponsored group (Gaouette and Greeley, 2011), using these digital media frameworks in creative ways located or identified each other, build solidarity around shared grievances, and identify collective political goals. It progressed through their use of the internet platforms to capture and circulate some inciting incidents, which state-controlled mainstream media ignores as cover-up. This stimulated public or mass anger against their governments, which led to street protests that were digitally coordinated and circulated across the whole world. The mobile phone generated video clips and recording of the protests, incidents of government clashes with the protesting trains, and other draconian actions against the leading activists were posted from different locations both rural and urban, which inadvertently drew the attentions of international governments, global Diasporas, and especially overseas news agencies into the movement (Howard and Hussain, 2013). The character of the ensuing protests in most of these North African countries made it difficult for states to respond. The demonstrations were rancorous while the demonstrators are relatively leaderless with little or no influence from unions, existing political parties, any form of defined political ideologies, or religious fervor. These culminated in some rulers conceding to the public pressure and meet public 
Table 1: Internet Users Statistics for Africa as @ September 26, 2019

\begin{tabular}{|c|c|c|c|c|c|c|}
\hline AFRICA & $\begin{array}{l}\text { Population } \\
\text { (2019 Est.) }\end{array}$ & $\begin{array}{c}\text { Internet } \\
\text { Users } \\
\text { 31-Dec-2000 }\end{array}$ & $\begin{array}{c}\text { Internet } \\
\text { Users } \\
\text { 30-June-2019 }\end{array}$ & $\begin{array}{c}\text { Penetration } \\
\text { (\% } \\
\text { Population) }\end{array}$ & $\begin{array}{c}\text { Internet } \\
\text { Growth \% } \\
2000-2019\end{array}$ & $\begin{array}{c}\text { Facebook } \\
\text { subscribers } \\
31-\text { Dec-2018 }\end{array}$ \\
\hline Algeria & $42,679,018$ & 50,000 & $25,428,159$ & $59.6 \%$ & $50,756 \%$ & $19,000,000$ \\
\hline Angola & $31,787,566$ & 30,000 & $7,078,067$ & $22.3 \%$ & $23,493 \%$ & $27,400,000$ \\
\hline Benin & $11,801,595$ & 15,000 & $3,801,758$ & $32.2 \%$ & $25,245 \%$ & 920,000 \\
\hline Botswana & $2,374,636$ & 15,000 & $1,116,079$ & $47.0 \%$ & $6,455 \%$ & 840,000 \\
\hline Burkina Faso & $20,321,560$ & 10,000 & $3,704,265$ & $18.2 \%$ & $36,942 \%$ & 840,000 \\
\hline Burundi & $11,575,964$ & 3,000 & 617,116 & $5.3 \%$ & $20,471 \%$ & 470,000 \\
\hline Cabo Verde & 560,349 & 8,000 & 352,120 & $62.8 \%$ & $4,302 \%$ & 240,000 \\
\hline Cameroon & $25,312,993$ & 20,000 & $6,128,422$ & $24.2 \%$ & $30,542 \%$ & $2,700,000$ \\
\hline Central African Rep. & $4,825,711$ & 1,500 & 256,432 & $5.3 \%$ & $16,995 \%$ & 96,000 \\
\hline Chad & $15,814,345$ & 1,000 & $1,027,932$ & $6.5 \%$ & $102,693 \%$ & 260,000 \\
\hline Comoros & 850,910 & 1,500 & 130,578 & $15.3 \%$ & $8,605 \%$ & 120,000 \\
\hline Congo & $5,542,197$ & 500 & 650,000 & $11.7 \%$ & $129,900 \%$ & 600,000 \\
\hline Congo, Dem. Rep. & $86,727,573$ & 500 & $7,475,917$ & $8.6 \%$ & $1,495,083 \%$ & $2,100,000$ \\
\hline Cote d'Ivoire & $25,531,083$ & 40,000 & $11,953,653$ & $46.8 \%$ & $29,784 \%$ & $3,800,000$ \\
\hline Djibouti & 985,690 & 1,400 & 548,832 & $55.7 \%$ & $39,102 \%$ & 180,000 \\
\hline Egypt & $101,168,745$ & 450,000 & $49,231,493$ & $48.7 \%$ & $10,840 \%$ & $35,000,000$ \\
\hline Equatorial Guinea & $1,360,104$ & 500 & 356,891 & $26.2 \%$ & $71,278 \%$ & 67,000 \\
\hline Eritrea & $5,309,659$ & 5,000 & 71,000 & $1.3 \%$ & $1,320 \%$ & 63,000 \\
\hline Eswatini & $1,415,414$ & 10,000 & 665,245 & $47.0 \%$ & $6,552 \%$ & 170,000 \\
\hline Ethiopia & $110,135,635$ & 10,000 & $20,507,255$ & $18.6 \%$ & $204,972 \%$ & $4,500,000$ \\
\hline Gabon & $2,109,099$ & 15,000 & $1,307,641$ & $62.0 \%$ & $8,617 \%$ & 620,000 \\
\hline Gambia & $2,228,075$ & 4,000 & 442,050 & $19.8 \%$ & $10,951 \%$ & 310,000 \\
\hline Ghana & $30,096,970$ & 30,000 & $11,737,818$ & $39.0 \%$ & $39,026 \%$ & $4,900,000$ \\
\hline Guinea & $13,398,180$ & 8,000 & $2,411,672$ & $18.0 \%$ & $30,046 \%$ & $1,500,000$ \\
\hline Guinea-Bissau & $1,953,723$ & 1,500 & 150,000 & $7.7 \%$ & $9,900 \%$ & 110,000 \\
\hline Kenya & $52,214,791$ & 200,000 & $46,870,422$ & $89.8 \%$ & $23,335 \%$ & $7,000,000$ \\
\hline Lesotho & $2,292,682$ & 4,000 & 682,990 & $29.8 \%$ & $16,975 \%$ & 310,000 \\
\hline Liberia & $4,977,720$ & 500 & $4,028,418$ & $80.9 \%$ & $805,584 \%$ & $4,028,418$ \\
\hline Libya & $6,569,864$ & 10,000 & $3,800,000$ & $57.8 \%$ & $37,900 \%$ & $3,500,000$ \\
\hline Madagascar & $26,969,642$ & 30,000 & $2,643,025$ & $9.8 \%$ & $8,710 \%$ & $1,700,000$ \\
\hline Malawi & $19,718,743$ & 15,000 & $2,717,243$ & $13.8 \%$ & $18,015 \%$ & 720,000 \\
\hline Mali & $19,689,140$ & 18,800 & $12,480,176$ & $63.4 \%$ & $66,284 \%$ & $1,500,000$ \\
\hline Mauritania & $4,661,149$ & 5,000 & 969,519 & $20.8 \%$ & $19,290 \%$ & 770,000 \\
\hline Mauritius & $1,271,368$ & 87,000 & 803,896 & $63.2 \%$ & $824 \%$ & 700,000 \\
\hline Mayotte (FR) & 266,380 & $\mathrm{n} / \mathrm{a}$ & 107,940 & $40.5 \%$ & $\mathrm{n} / \mathrm{a}$ & 71,000 \\
\hline Morocco & $36,635,156$ & 100,000 & $23,739,581$ & $64.8 \%$ & $23,640 \%$ & $15,000,000$ \\
\hline Mozambique & $31,408,823$ & 30,000 & $6,523,613$ & $20.8 \%$ & $21,645 \%$ & $1,800,000$ \\
\hline Namibia & $2,641,996$ & 30,000 & $1,347,418$ & $51.0 \%$ & $4,391 \%$ & 570,000 \\
\hline Niger & $23,176,691$ & 5,000 & $2,368,658$ & $10.2 \%$ & $47,273 \%$ & 440,000 \\
\hline Nigeria & $200,962,417$ & 200,000 & $123,486,615$ & $61.4 \%$ & $61,643 \%$ & $17,000,000$ \\
\hline Reunion (FR) & 889,918 & 130,000 & 480,000 & $53.9 \%$ & $269 \%$ & 420,000 \\
\hline Rwanda & $12,794,412$ & 5,000 & $5,981,638$ & $46.8 \%$ & $119,532 \%$ & 490,000 \\
\hline Saint Helena & 4,096 & $\mathrm{n} / \mathrm{a}$ & 2,200 & $53.7 \%$ & $\mathrm{n} / \mathrm{a}$ & 1,700 \\
\hline $\begin{array}{l}\text { Sao Tome \& } \\
\text { Principe }\end{array}$ & 213,379 & 6,500 & 63,864 & $29.9 \%$ & $882 \%$ & 52,000 \\
\hline Senegal & $16,743,859$ & 40,000 & $9,749,527$ & $58.2 \%$ & $24,274 \%$ & $2,900,000$ \\
\hline Seychelles & 95,702 & 6,000 & 67,119 & $70.1 \%$ & $1,018 \%$ & 61,000 \\
\hline Sierra Leone & $7,883,123$ & 5,000 & $1,043,725$ & $13.2 \%$ & $20,774 \%$ & 450,000 \\
\hline Somalia & $15,636,171$ & 200 & $1,500,000$ & $9.6 \%$ & $749,900 \%$ & $1,100,000$ \\
\hline South Africa & $58,065,097$ & $2,400,000$ & $32,615,165$ & $56.2 \%$ & $1,259 \%$ & $16,000,000$ \\
\hline South Sudan & $13,263,184$ & $\mathrm{n} / \mathrm{a}$ & $2,229,963$ & $16.8 \%$ & $\mathrm{n} / \mathrm{a}$ & 180,000 \\
\hline Sudan & $42,514,094$ & 30,000 & $13,124,100$ & $30.9 \%$ & $43,647 \%$ & $2,600,000$ \\
\hline Tanzania & $60,913,557$ & 115,000 & $23,142,960$ & $38.0 \%$ & $20,024 \%$ & $6,100,000$ \\
\hline Togo & $8,186,384$ & 100,000 & $1,011,837$ & $12.4 \%$ & $912 \%$ & 560,000 \\
\hline Tunisia & $11,783,168$ & 100,000 & $7,898,534$ & $67.0 \%$ & $7,798 \%$ & $6,400,000$ \\
\hline Uganda & $45,711,874$ & 40,000 & $18,502,166$ & $40.5 \%$ & $46,155 \%$ & $2,600,000$ \\
\hline Western Sahara & 582,478 & $\mathrm{n} / \mathrm{a}$ & 28,000 & $4.8 \%$ & $\mathrm{n} / \mathrm{a}$ & 24,000 \\
\hline Zambia & $18,137,369$ & 20,000 & $7,248,773$ & $40.0 \%$ & $36,144 \%$ & $1,600,000$ \\
\hline Zimbabwe & $17,297,495$ & 50,000 & $8,400,000$ & $48.6 \%$ & $16,700 \%$ & 880,000 \\
\hline TOTAL & $1,320,038,716$ & $4,514,400$ & $522,809,480$ & $39.6 \%$ & $11,481 \%$ & $204,304,118$ \\
\hline
\end{tabular}

Source: Miniwatts Marketing Group, 2019 
demands in Egypt and Tunisia, and a form of protracted stalemate in Libya.

In Nigeria, the use of mobile phones to gather and disseminate information has being a veritable platform for political activities in rural and urban areas such as electioneering, political participation, news gathering and dissemination. Millions of Nigerian citizens (rural dwellers inclusive) "surf the web, creating their own account profiles and sharing information online, (and making) a substantial amount of data becomes available" (Ceron, Curini, and lacus, 2015: 1). The social media such as Facebook, WhatsApp, Twitter, Google, and YouTube has prevailed as the major channel of information gathering and dissemination among Nigerians. It has being a platform for all forms of interaction, activism, campaign and mass mobilization (Bennett and Segerberg, 2011; Larsson and Moe, 2012; Ceron, Curini and lacus, 2013; Ceron and d'Adda, 2015). It became a platform for unlimited and continuous free interaction among the masses/users where common response to socio-economic and political issues such election results are shared (Suntai and Targema, 2015).

The list and details of people's use of ICTs such as mobile phones to generate or gather news/information across Africa and disseminate same through social media platforms is endless. Zimbabue and South Africa are other good examples. In Zimbabwe, the media is heavily dominated by state owned and controlled communication institutions, and it only serves as a means to spread the ruling Zanu PF government policy and stifle dissenting voices (Kelley and Donway, 1990; Ronning, 2005). The few existing private press seems to have signed a pact with government to "hear no evil", "speak no evil" and "see no evil" regarding its affairs' (Chari, 2009: 10). To this point, there were no freedom of speech and expression; people use fake names for security reasons due to dictatorship.

However, through the instrumentality of mobile phones and social media, opposition activists established powerful groups and movements through posting of video clips, pictures, and actions of government that are anti-public interests. Like Africans in the North, they created contacts and relations among themselves, the masses, Zimbabweans in Diaspora, and the rest of the world. The synthesis of their pressures and activism was the establishment of synergy between the people, activists, the armed forces; Europe and America that led the emergence of strong opposition, which eventually forced the long reigning dictator, Robert Mugabe, to step down from office. It is therefore innocuous to aver that majority of Africans, rural dwellers inclusive, are internet users who use to generate and circulate information/news through internet platforms.

Has the emergence of new information technologies affected the process, the quantity and quality of news gathering in rural African communities?

The need for efficient, reliable and affordable communication system is essential. This is because it provides unique opportunity for African rural dwellers to contact and relate with their relations, neighbours, and acquaintances living in distant locations in the hinterlands and urban areas. With it, they engage in socio-cultural, political, and economic relations, transactions, and activities without any obstacle or barriers and at lesser costs (Mishra, 2016; Debora, 2012; Behnke, 2010).

Consequently, its emergence dominated and changed the character, mode, processes and interaction patterns among rural dwellers. These are more individualised, informal, unprepared with less emphasis on physical meetings while news are no longer solicited for before they are generated and spread. No law or principle guides news gathering and dissemination neither does it consider or require the interest of would be consumers. All take place at the instance and pleasure or interest of the individual who is experiencing the events that constitute the news. Due to its individualised nature, all interests and status are accommodated by citizens' journalism in this era of new media. Thus, an analysis of its impact reveals the enthronement of cultural flux, alteration of state media monopoly of news gathering and dissemination theatre, and public opinion formation (Uwakwe, 2012). It has drastically changed the life style of youths, pattern and processes of mobilisation, and opened new channels of economic and business enterprises (Udeze, 2012).

Specifically, the introduction of new media and its tools, which have user friendly interface as well as internet penetration through mobile phones has democratized the media space and allow dwellers in the rural areas to reach out to the masses every day to share their experiences across multiple platforms, circumventing mainstream media and government censorship/hindrances (Lewis, Holton, \& Coddington, 2014). It tends to amplify news from rural communities or hinterlands by filling the gap created by mainstream media inability to cover activities in such areas to a larger more audience. News/information from rural communities is gaining increasing attention in the urban areas and beyond their respective regions and countries to the entire world due courtesy citizen journalism (Konieczna \& Robinson, 2014; Prado, 2017). The inhabitants of the rural areas have showcased their willingness to report news that matters to them and their community development, security, and peace without the consideration of government policy and political interest. It has tremendously changed the way people gather information and their distribution options, and the nature of its relationship with the mainstream media (Serra, 2013).

What are the major problems hindering the effective adoption or application of internet-mediated-technologies approach to newsgathering in rural Africa?

The literature is perverse with challenges facing citizens' journalism or the use of mobile phones and other technologies by rural residents or people residing in African hinterlands to generate and disseminate information. Apuke (2016) and Okon (2001) observed that the new information and communication technologies and its associated media forms are alien to most residents of African hinterlands. This is as a result of their level of education, age, and complete lack of requisite knowledge and skills to use the phenomena. Most of them find it difficult, if not impossible, to adopt and adapt to state-of-theart phones/equipment in gathering, processing, packaging and disseminating news and other relevant information to the public.

In addition to the above challenge, many areas in the hinterlands are very remote that government and communication industries find it less important and economically unattractive to establish or locate ICTs facilities such as communication Masks in such areas. Many towns and villages in rural Africa do not have access to internet services. This renders the news or information captured by residents through mobile phones useless as they could not be dispersed or circulated due to lack of accessible network. Such people cannot also access news gathered by distant neighbours and the world at large. Thus, citizen journalism is highly limited in the hinterlands where there is no communication Masks and network.

Poverty and the character of rural economy where over $90 \%$ of rural inhabitants are peasant farmers are primary factors challenging citizen journalism. First, they do not 
have enough to take care of 'essential needs' such as food, shelter and clothing. Adjunct to the above, high cost of ICTs products such as phone and its accessories, data, and airtime pose a serious challenge to citizen journalism. Consequently, they are not considering the purchase of mobile phones, airtime, and data as essential even if they know how to use them. Secondly, they are tightly committed to farming and market activities that they hardly enjoy leisure time, which would have enabled them to connect frequently to internet for information or news circulation.

Citizen journalism in rural Africa is also faced with the challenges of news duplication, circulation of rumours or false information, and wrong misleading information. Although one has to acknowledge that mainstream media is not bereft of the same crime but that of citizen journalism is enormous. At times, they generate and circulate propagandas with the intention to annoy or cause anger, promote injustice or even create enmity among the targeted audience. For instance, during the 2015 Nigeria general elections, most of the news circulated through social media were propagandas and false fermented to ensure that $\mathrm{Dr}$ GoodLuck Ebele Jonathan - a Southerner and Christian did not win a second term as president. Similar news dominated the social media in 2019 general elections against Muhamadu Buhari's second term bid See also (Conradie \& Jacobs, 2003; Taylor, 2004; International Telecommunication Union, 2001; Mwanjoka, 2002).

\section{CONCLUSION}

Innovations and inventions led to the emergence of the new Information and Communication Technologies (ICT), which has inadvertently altered and enhance the existing communication process and its contents. It expanded the frontier of communication channels to include online information services, cable networks, the internet and World Wide Web, among others. This, which has been termed the new media, enhances the reach and understanding of mainstream media and inculcated untrained individuals participation in newsgathering and circulation known as citizen journalism across the world. Residents became consumers and contributors at the same time (Couldry \& Dreher, 2007; Hess, 2013). By this, the world became smaller in terms of information generation and dissemination, while communication process became more rapid and highly cost-effective.

The emergence of citizen journalism has, thus, bridged the gap created by mainstream media in newsgathering and circulation. Inevitably, it empowered residents of rural areas or hinterlands in Africa as well as other continents not only to access news in their domain and the world in general but also to generate and circulate news from their environment using mobile phones and other ICTs. Fundamentally, this altered or changed the nature and processes of newsgathering and dissemination, news consumption, and neutralised the negative effect of state censorship on publicising mass opinion and raw information from rural communities. This opened up many new professional and economic opportunities in the hinterlands.

Nevertheless, citizen journalism in African hinterlands is confronted with numerous issues and challenges associated with ICTs as the central or primary channel of new media. factors ranging from lack of skills, poverty and the character of rural economy, costs of ICTs and the rapid changes in their models, none availability of communication masks and others tend to hinder the effectiveness of citizen journalism in rural Africa.

It is therefore recommended that:

a. Communication conglomerates or institutions should pursue multiple construction of communication Masks across rural areas in Africa. Its implementation shall enhance easy access to network among residents.

b. ICTs Multipurpose Community Centres (MPCCs) should be established to provide free ICTs education and training in the rural areas in order to solve the problem of illiteracy and lack of skills. Such centres shall also respond to local demands or stimulate a demand for their services and job provision. According to Wellenius (2003), development will not be achieved if one relies solely on the profit driven private sector investments in the provision of ICT services. Consequently, this requires the intervention of NGOs, government agencies, international conglomerates and donor agencies.

c. Manufacturers of ICTs and mobile phone should develop low-cost products with internet feature with simple designs that can easily be understood and used by villagers in rural Africa. Such products shall be hotly contested for.

d. ICTs industries should embark on the production of solar powered mobile phones as a panacea for absence or lack of regular energy supply in rural areas.

e. In addition, communication networks should review the costs of their data plan and airtime downwards specifically for people living in the rural areas to enable them remain constantly connected online in spite of their poor economy. Simply put, they should promote an affordable universal access and universal services in ICTs for African hinterlands.

\section{REFERENCES}

Adams, D. (2006). Journalism, citizens and blogging. In Proceedings 2006 Communications Policy and Research Forum. University of Technology Sydney (UTS) Australia.

Agbodike, C. C. (1992). Mass mobilization and rural development in Nigeria: An appraisal. In Olisa, M. and Obiukwu, J. I. (Eds.). Rural Development in Nigeria: Dynamics and Strategies. Awka; Mekslink Publishers.

Allan, S. (2009). Online news: Journalism and the internet. England: Open University Press.

Apuke, O. D. (2016). Information Communication Technology and Citizen Journalism in Nigeria: Pros and Cons. Higher Education of Social Science, 11 (4): 1-4. Available from http://www.cscanada.net/index.php/hess/article/view/9027.

Bappah, M. A. (2010). Availability and use of Information and Communication Technology (ICT) in six Nigerian university library schools. Retrieved from www.webpages.uidaho. edu/ $\sim$ mbolin/bappah-abubakar.html.

Bennett, W. L. \& Segerberg, A. (2011). Digital media and the personalization of collective action: Social technology and the organization of protests against the global economic crisis. Information Communication and Society. 14(6): 770-799.

Blaukopf, K. (1992). Musical life in a changing society. London: Amedeus Press.

Böhme, C. (2013). Look with your own eyes! Visualization of spirit media and their viewing techniques in Tanzanian video films. In Heike Behrend, Anja Dreschke \& Martin Zillinger (Eds.). Trance Mediums and New Media. New York: Fordham University Press. DOI: 10.5422/fordham/9780823253807.003.0012.

Bonds-Raacke, J., \& Raacke, J. (2010). MySpace and Facebook: Identifying dimensions of uses and gratifications for friend networking sites. Individual Differences Research. 8(1): 27-33.

Boyd, D. \& Ellison, N. (2007). Social Network Sites: Definition, History, and Scholarship. Journal of Computer-Mediated Communication. 13(1): 210130. DOI: https://doi.org/10.1111/j.10836101.2007.00393.x.

Brautovic, Mato (2009). Usage of newsroom computer systems 
as indicator of media organization and production trends: Speed, Control and Centralization. Medijska istraživanja: znanstveno-stručni časopis za novinarstvo i medije, 15(1).

Brooks, B. S. et al (1980). News Reporting and Writing. New York: St. Martin's Press.

Castells, M. (2001). The internet galaxy: Reflections on the internet, business and society. UK: Oxford University press.

Ceron, A. and d'Adda, G. (2015). E-campaigning on Twitter: The effectiveness of distributive promises and negative campaign in the 2013 Italian election. New media \& society. 18 (9). DOI: $10.1177 / 1461444815571915$

Ceron, A., Curini, L., \& lacus, S. M. (2013). Social Media: Sentiment Analysis. L'evoluzione dei fenomeni sociali attraverso la Rete. Springer, Milano. DOI: https://doi.org/10.1007/978-88-4705532-2.

Ceron, A., Curini, L., \& lacus, S. M. (2015). Using sentiment analysis to monitor electoral campaigns: method matters: Evidence from the United States and Italy. Social Science Computer Review, 33(1): 3-20. DOI: https://doi.org/10.1177/0894439314521983.

Chadwick, A. \& Simon, C. (2014). Boundary-Drawing power and the renewal of professional news organizations: The case of the Guardian and the Edward Snowden National Security Agency Leak. International Journal of Communication, 8: 2420-2441.

Chari, I. (2009). Ethical challenges facing Zimbabwean media in the context of the internet. Global Media Journal, African Edition, 3. DOI: https://doi.org/10.5789/3-1-19.

Couldry, N. \& Dreher, T. (2007). Globalization and the public sphere: Exploring the space of community media in Sydney. Global Media and Communication. 3(1): 79-100. DOI: http://doi.org/ $10.1177 / 1742766507074360$.

Conradie, D. P. \& Jacobs, S. J. (2003). Challenges encountered when using ICTs (Information and Communication Technologies) in support of development in rural African communities. Engineering Management. 30-33, February.

De Vries, F. (2008). Blogs in the mainstream media: an exploration of a code of ethical conduct for j-bloggers at Die Burger Western Cape. MPhil (Journalism) thesis, University of Stellenbosch, South Africa.

Debora, D. (2012). Finding high quality in social media. International Conference on Web Search and Data Mining. Calabar: WSDM.

Dennis, E. E. \& Ismach, A. H. (1981). Reporting Processes and Practices: Newswriting for Today's Readers. Belmont, California: Wadsworth Publishing Company.

Deuze, M. (2008). Understanding journalism as news work: How it changes, and how it remains the same. Westminster Papers in Communication and Culture. 5(2): 4-23. Retrieved from https://www.westminster.ac.uk/file/7101/download?token=oEuWDfow.

de Witte, M. (2011). Business of the Spirit: Ghanaian broadcast media and the commercial exploitation of pentecostalism. Journal of African Media Studies. 3 (2): 189-204

Dominick, J. R. (2013). The dynamics of mass communication (12 ${ }^{\text {th }}$ Edn.). US: McGraw-Hill International Company.

Donath, J. (2004). Sociable media. In Sims Bainbridge, W. (Ed.) The Encyclopedia of Human Computer Interaction. Great Barrington, MA: Berkshire Publishing Group.

Englert, B. \& Moreto, N. P. (2010). Inserting Voice: Foreign language film translation into Kiswahili as a Local Phenomenon in Tanzania. Journal of African Media Studies, 2(2): 225-239. DOI: https://doi.org/10.1386/jams.2.2.225 1.

Erwin, G. \& Taylor, W. (2004). Social appropriation of Internet Technology: A South African platform. The Journal of Community Informatics. 1(1): 21-29.

Esipisu, I. \& Kariithi, K. (2007). New Media Development in Africa. Global Media Journal: Africa Edition. Retrieved from http:// academic.sun.ac.za/gmja/Academic.htm.

Ettema, J. S., Whitney, D. C., \& Wackman, D. B. (1997). Professional Mass Communicators. In Berkowitz, D. (Ed.). Social meanings of news: A textual reader. London: Sage.
Fidler, R. (1997). Mediamorphosis: Understanding new media. London: Sage Publications.

Flew, T. (2009). Online Media and User-Created Content: Case Studies in News Media Reposting in the Australian Media Environment. In: Media after the Mass, European Media Management Association Annual Conference, 13-14 February 2009, Paris, France.

Foss, K. (2008). Ordinary Citizens Redefining News-Gathering. The Star. 15 September. Retrieved from http://.thestar.co.za/ index.php?fSectionld=\&fArticleld=vn20089 $15055712809 \mathrm{C}$ 852277.

Freedman, E., \& Shafer, R. (2012). Challenges Facing Press Freedom in the Baltics Two Decades after Independence. JRE Journal. 2(2): 1-29.

Gerlitz, C. (2011). What counts? Reflections on the multivalence of social media data. Digital Culture \& Society. 2 (2): 19-38.

Gicheru, C. W. (2014). The Challenges Facing Independent Newspapers in Sub-Saharan Africa. University of Oxford's Reuters Institute Fellowship Paper.

Gillmor, Dan (2006). We the media: Grassroots journalism by the people, for the people. Sebastopol, California: O' Reilly.

Goldfain, K. \& Van der Merwe, N. (2006). The role of the political blog: the case of www.commentary.co.za. Communicare: 103-124.

Harrison, T. \& Barthel, B. (2009). Wielding new media in Web 2.0: Exploring the history of engagement with the collaborative construction of media products. New Media \& Society, 11 (1-2). DOI: http://doi.org/10.1177/1461444808099580.

Heinonen, A. (2011). The journalists' relationships with users: New dimensions to conventional roles. In Singer J. et al. (Eds.). Participatory Journalism. Chichester: Wiley-Blackwell. DOI: https://doi.org/10.1002/9781444340747.ch3.

Hermida, A. (2011). Twittering the news. Journalism Practice. 4(3): 297-308. DOI: https://doi.org/10.1080/17512781003640703.

Hermida, A. (2012). Social journalism: exploring how social media is shaping journalism. In Siapera, E. \& Veglis, A. (Eds.). The handbook of global online journalism. West. Sussex: WileyBlackwell, pp. 309-328. DOI: https://doi.org/10.1002/9781118313978.ch17.

Hess, K. (2013). Breaking Boundaries. Digital Journalism. 1(1): 48-63. DOI: http://doi.org/10.1080/21670811.2012.714933.

Holcomb, J. et al (2011). How mainstream media outlets use Twitter. Pew Research Canter's Project for excellence in Journalism.

Howard, P. N. \& Hussain, M. M. (2013). Democracy's Fourth Wave? Digital Media and the Arab Spring. New York: Oxford University press

Hultin, J. \& Skog, D. (2011). The digitalized newspaper organization: An identity crisis in the midst of the challenges of being early adopters of converged digital services. Retrieved from: www.diva-potal.org

Hydén, G., Leslie, M., Ogundimu, F. F. \& Hyden, G. (Eds.) (2002). Media and Democracy in Africa. New Brunswick, NJ: Transaction Publishers.

International Telecommunication Union (ITU) (2001). Internet Users. Statistics and Indicators.

Johnston, J. \& Forde, S. (2011). The silent partner: News agencies and $21^{\text {st }}$ Century News. International Journal of Communication. 5(1)

Joseph, J. (2013). The EU in the Horn of Africa: Building Resilience as a Distant Form of Governance. Journal of Common Market Studies. 1-17. DOI: https://doi.org/10.1111/jcms.12085.

Kaid, L. (2009). Changing and staying the same: communication in campaign 2008. Journalism Studies. 10(3): 417-423. DOI: https://doi.org/10.1080/14616700902812728.

Kaplan, A. \& Haenlein, M. (2010). Users of the world, unite! The challenges and opportunities of social media. Business Horizons. 53(1): 59-68. DOI: https://doi.org/10.1016/j.bushor.2009.09.003.

Konieczna, M. \& Robinson, S. (2014). Emerging news non-profits: 
A case study for rebuilding community trust? Journalism. 15(8): 968-986. DOI: http://doi.org/10.1177/ 1464884913505997.

Kovac, M. \& Rosenthal, M. (2001). The elements of journalism: What news people should know and the public should expect. New York: Crown Publishers.

Kupe, T. (2003). The Untold $21^{\text {st }}$ Century Story. Rhodes Journalism Review. (23): 1-20.

Larkin, B. (2004). Degraded Images, Distorted Sounds: Nigerian Video and the Infrastructure of Piracy. Public Culture. 16 (2): 289-314. DOI: https://doi.org/10.1215/08992363-16-2-289.

Larsson, A. O. \& Moe, H. (2012). Studying political microblogging: Twitter users in the 2010 Swedish election campaign. New Media \& Society. 14(5): 729-747. DOI: https://doi.org/10.1177/ 1461444811422894.

Lee-Wright, P. (2010). Culture Shock: New Media and organisational change in the BBC. In N. Fenton (Ed.). New Media, Old News: Journalism and Democracy in the Digital Age. London: Sage.

Lewis, D. \& Mosse, D. (2006). Development Brokers and Translators: The Ethnography of Aid and Agencies. Bloomfield, CT: Kumarian Press.

Lewis, S. C., Holton, A. E., \& Coddington, M. (2014). Reciprocal journalism: A concept of mutual exchange between journalists and audiences. Journalism Practice. 8(2): 29-241. DOI: http:/ /doi.org/10.1080/17512786.2013.859840.

Lowrey, W. (2006). Mapping the Journalism-Blogging Relationship. Journalism. 7(4): 477-500. DOI: https://doi.org/10.1177/ 1464884906068363

Matsiola, M. (2008). New technological tools in contemporary journalism: Study concerning their utilization by the Greek journalists related to the use of the internet as a mass medium. Unpublished PhD thesis, Department of Journalism and Mass Media, Aristotle University of Thessaloniki.

Mchakulu, J. E. (2007). How did we ever manage without them in the past? Journalists' Use of Computers and Mobile Telephones. Paper presented at the Communication Technologies of Empowerment Postgraduate Research Conference, Institute of Communications Studies (ICS), University of Leeds, 18 May.

McNair, B. (1998). The Sociology of Journalism. London: Arnold.

Meyer, B. (2010). Introduction: From Imagined Communities to Aesthetic Formations: Religious Mediations, Sensational Forms and Styles of Binding. In Birgit Meyer (Ed.). Aesthetic Formations: Media, Religion and the Senses. New York: Palgrave Macmillan.

Mishra, R. (2016). Digital democracy and student politics: Interpretation from Assam university student's council elections. International Journal of Management Humanities and Social Sciences. 1(1): 46-54.

Moyo, D. (2009). Citizen Journalism and the Parallel Market of Information in Zimbabwe's 2008 Election. Journalism Studies. 10(4): 551-567. DOI: https://doi.org/10.1080/14616700902797291.

Mudhai, F. (2004). Researching the impact of ICTs as change catalysts in Africa. Ecquid Novi: South African Journal for Journalism Research. 25(2): 313-335.

Mwanjoka, O. (2002). Final workshop report: Introduction of information and communication technologies in rural areas. Available at: http://www.ics.trieste.it/ documents/hightech/ telecom/activities/wsdec2002/Final\%20Report.pdf.

Newman, N., William, H. D., \& Grant, B. (2012). Social Media in the Changing Ecol-ogy of News: The Fourth and Fifth Estates in Britain. International Journal of Internet Science. 7(1): 6-22.

Njogu, K., \& Middleton, J. (Eds.) (2009). Media and Identity in Africa. Edinburgh: Edinburgh University Press.

Nwosu, I. E. (1986). Mobilizing people's support for development: An analysis of public enlightenment campaigns in Africa. Africa Media Review. 1(1): 48-65.

O'Sullivan, J. (2005). Delivering Ireland: Journalism's search for a role online. Gazette. 67(1): 45-68.

Obeng-Quaidoo, I. (1986). A proposal for New Communication Research Methodologies in Africa. Africa Media Review. 1(1): 89-98.
Okon, G. B. (2001). Basic dimensions in mass communication. Lagos, Nigeria: HdX Communications LTD.

Pavlik, J. V. (2001). Journalism and new media. New York: Columbia University Press. Available at: http://icankihsan.weebly.com/uploads/1/8/7/4/18748648/journalismandn ew_media.pdf.

Pew Research Centre (2010). The State of the News Media. New York: Project for Excellence in Journalism and Pew Internet and American Life Project. Available at http://stateofthemedia.org/2010/online-summaryessay/.

Picard, R. G. (2014). Media Firms: Structures, Operations, and Performance. London: Routledge.

Prado, P. (2017). Mapping citizen journalism and the promise of digital inclusion: A perspective from the Global South. Global Media and Communication. 13(2): 1-18.

Quinn, S. and Quinn-Allan, D. (2005). The world-wide spread of journalism convergence. Refereed paper presented to the Journalism Education Conference, Griffith University, 29 November - 2 December, School of Communication and Creative Arts Deakin University.

Rosen, J. (2008). A Most Useful Definition of Citizen Journalism. In Wikipedia.

Saul, M. \& Austen, R. A. (2010). Viewing African Cinema in the Twenty-first Century: Art Films and the Nollywood Video Revolution. Athens: Ohio University Press.

Serra, S. (2013). Citizen Journalism. AIP Scholaris. 2(1): 1-16. Available at http://scholaris.vse.cz/index.php/scholaris/article/ download/14/10.

Shipley, J. W. (2009). Aesthetic of the Entrepreneur: Afro-cosmopolitan Rap and Moral Circulation in Accra, Ghana. Anthropological Quarterly. 82 (3): 631-68.

Siapera, Eugenia, Lambrini, Papadopoulou, \& Fragiskos, Archontakis (2014). Post-Crisis Journalism. Journalism Studies, 16 (3): 449-465. DOI: 10.1080/1461670X.2014.916479.

Sperlich, R. (2006). Mediamorphosis of cultural creation and a study of the digital mediamorphosis in rock and electronic music in Austria. A Paper presented at the Media Change and Social Theory Conference in Oxford Session 604-a, September 7, 2006. Available at http://users.auth.gr/baltzis/ papers/seminar_04_mediamorphosis.pdf.

Spitulnik, D. (2002). Alternative Small Media and Communicative Spaces. In Göran, Hydén; Michael, Leslie; Folu F., Ogundimu; and Goran, Hyden (Eds.). Media and Democracy in Africa. New Brunswick, NJ: Transaction Publishers.

Spyridou, L. P. (2009). Journalistic content on the web: Studying interactivity in Greek online newspapers. Unpublished PhD thesis, Department of Journalism and Mass Media, Aristotle University of Thessaloniki.

Suntai, D. I. \& Targema, T. S. (2015). Social media and democracy in Africa: assessing the 2015 general election experience in Nigeria. Paper presented at the International Conference on Democracy, Dictatorship and Development in Africa. Department of History and International Studies. Ibrahim Badamasi Babangida University, Lappi. 2-5 August.

Tapscott, D. \& Williams, A. D. (2006). Wikinomics: How Mass Collaboration Changes Everything. New York: Penguin.

Tomno, C. J. (2012). Journalism and social media. Centre for International Media Ethics (CIME): Nairobi, Kenya.

Udeze, S. E. (2012). Media law and ethics. Enugu, Nigeria: Rhyce Kerex Publishers Limited.

Ugwuanyi, C., Gever, V. C. \& Olijo, I. (2019). Social media as tools for political views expressed in the visuals Shared among social media users, Library Philosophy and Practice: 1-19.

Uwakwe, O. (2012). Media writing and reporting: who, what, when, where and how (3rd ed.). Enugu, Nigeria: Cecta Books.

Veglis, A. (2012). Journalism and cross media publishing: the case of Greece. In: Siapera E., Veglis A. (Eds.). Handbook of online journalism. The Wiley-Blackwell.

Verclas, K. \& Mechael, P. (2008). A Mobile Voice: The Use of Mobile Phones in Citizen Media. Washington: United States 
Agency for International Development. Available at http:// www.usaid.gov/about_usaid/hrd/A_Mobile_Voice.pdf.

Vodafone (2005). Africa, the impact of mobile phones: Moving the debate forward. Vodafone Policy Papers Series No. 2. Vodafone Group.

Wasserman, H. (2011). Popular Media, Democracy and Development in Africa. London: Routledge.

Wogu, Joseph; Ezeah, Greg; Gever, Verlumun Celestine; Ugwuanyi, John Chidi (2019). Politicking in the digital age: engagement in computer-mediated political communication and citizens' perception of political parties, politicians and the government. Library Philosophy and Practice. 1-20.

\section{LIST OF REFERENCE LINKS}

Adams D. Journalism, citizens and blogging. Proceedings 2006 Communications Policy and Research Forum. University of Technology Sydney (UTS) Australia, 2006.

Agbodike C. C. Mass mobilization and rural development in Nigeria: An appraisal. Rural Development in Nigeria: Dynamics and Strategies / Olisa M. and Obiukwu J. I. (Eds.). Awka; Mekslink Publishers, 1992

Allan S. Online news: Journalism and the internet. England: Open University Press, 2009.

Apuke O. D. Information Communication Technology and Citizen Journalism in Nigeria: Pros and Cons. Higher Education of Social Science. 2016. 11 (4). Pp. 1-4. URL: http://www.cscanada.net/index.php/hess/article/view/9027.

Bappah M. A. Availability and use of Information and Communication Technology (ICT) in six Nigerian university library schools. 2010. URL: www.webpages.uidaho. edu/ mbolin/bappahabubakar.html.

Bennett W. L. \& Segerberg A. Digital media and the personalization of collective action: Social technology and the organization of protests against the global economic crisis. Information Communication and Society. 2011. 14(6). Pp. 770-799.

Blaukopf K. Musical life in a changing society. London: Amedeus Press, 1992.

Böhme C. Look with your own eyes! Visualization of spirit media and their viewing techniques in Tanzanian video films. Trance Mediums and New Media / Heike Behrend, Anja Dreschke \& Martin Zillinger (Eds.). New York: Fordham University Press, 2013. DOI: $10.5422 /$ fordham/9780823253807.003.0012.

Bonds-Raacke J. \& Raacke J. MySpace and Facebook: Identifying dimensions of uses and gratifications for friend networking sites. Individual Differences Research. 2010. 8(1). Pp. 27-33.

Boyd D. \& Ellison N. Social Network Sites: Definition, History, and Scholarship. Journal of Computer-Mediated Communication. 2007. 13(1). DOI: https://doi.org/10.1111/j.1083-6101.2007.00393.x.

Brautovic Mato. Usage of newsroom computer systems as indicator of media organization and production trends: Speed, Control and Centralization. Medijska istraživanja: znanstvenostručni časopis za novinarstvo i medije. 2009. 15(1).

Brooks B. S. et al. News Reporting and Writing. New York: St. Martin's Press, 1980

Castells M. The internet galaxy: Reflections on the internet, business and society. UK: Oxford University press, 2001.

Ceron A., Curini L., lacus S. M. Social Media: Sentiment Analysis. L'evoluzione dei fenomeni sociali attraverso la Rete. Springer Milano, 2013. DOI: https://doi.org/10.1007/978-88-470-5532-2.

Ceron A., Curini L., lacus S. M. Using sentiment analysis to monitor electoral campaigns: method matters: Evidence from the United States and Italy. Social Science Computer Review. 2015. 33(1). Pp. 3-20. DOI: https://doi.org/10.1177/0894439314521983.

Ceron A., d'Adda G. E-campaigning on Twitter: The effectiveness of distributive promises and negative campaign in the 2013 Italian election. New media \& society. 2015. 18 (9). DOI: 10.1177/1461444815571915.

Chadwick A. \& Simon C. Boundary-Drawing power and the renewal of professional news organizations: The case of the Guardian and the Edward Snowden National Security Agency Leak. International Journal of Communication. 2014. 8. Pp. $2420-2441$.

Chari I. Ethical challenges facing Zimbabwean media in the context of the internet. Global Media Journal, African Edition. 2009. 3. DOI: https://doi.org/10.5789/3-1-19.

Conradie D. P., Jacobs S. J. Challenges encountered when using ICTs (Information and Communication Technologies) in support of development in rural African communities. Engineering Management. 2003. 30-33, February.

Couldry N., Dreher T. Globalization and the public sphere: Exploring the space of community media in Sydney. Global Media and Communication. 2007. 3(1). Pp. 79-100. DOI: http://doi.org/ $10.1177 / 1742766507074360$.

De Vries F. Blogs in the mainstream media: an exploration of a code of ethical conduct for $\mathrm{j}$-bloggers at Die Burger Western Cape. MPhil (Journalism) thesis, University of Stellenbosch, South Africa, 2008

de Witte M. Business of the Spirit: Ghanaian broadcast media and the commercial exploitation of pentecostalism. Journal of African Media Studies. 2011. 3 (2). Pp. 189-204.

Debora D. Finding high quality in social media. International Conference on Web Search and Data Mining. Calabar: WSDM, 2012.

Dennis E. E., Ismach A. H. Reporting Processes and Practices: Newswriting for Today's Readers. Belmont, California: Wadsworth Publishing Company, 1981.

Deuze M. Understanding journalism as news work: How it changes, and how it remains the same. Westminster Papers in Communication and Culture. 2008. 5(2). Pp. 4-23. URL: https://www.westminster.ac.uk/file/7101/download?token=oEuWDfow.

Dominick J. R. The dynamics of mass communication (12th Edn.). US: McGraw-Hill International Company, 2013.

Donath J. Sociable media. The Encyclopedia of Human Computer Interaction / Sims Bainbridge W. (Ed.). Great Barrington, MA: Berkshire Publishing Group, 2004

Englert B., Moreto N. P. Inserting Voice: Foreign language film translation into Kiswahili as a Local Phenomenon in Tanzania. Journal of African Media Studies. 2010. 2(2). Pp. 225-239. DOI: https://doi.org/10.1386/jams.2.2.225_1.

Erwin G., Taylor W. Social appropriation of Internet Technology: A South African platform. The Journal of Community Informatics. 2004. 1(1). Pp. 21-29.

Esipisu I., Kariithi K. New Media Development in Africa. Global Media Journal: Africa Edition. 2007. URL: http://academic.sun.ac.za/gmja/Academic.htm.

Ettema J. S., Whitney D. C., Wackman D. B. Professional Mass Communicators. Social meanings of news: A textual reader I Berkowitz D. (Ed.). London: Sage, 1997.

Fidler R. Mediamorphosis: Understanding new media. London: Sage Publications, 1997.

Flew T. Online Media and User-Created Content: Case Studies in News Media Reposting in the Australian Media Environment. Media after the Mass, European Media Management Association Annual Conference, 13-14 February 2009, Paris, 2009.

Foss K. Ordinary Citizens Redefining News-Gathering. The Star. 15 September. 2008. URL: http://.thestar.co.za/index.php?fSectionld=\&fArticleld=vn20089 15055712809 C852277.

Freedman E., Shafer R. Challenges Facing Press Freedom in the Baltics Two Decades after Independence. JRE Journal. 2012. 2(2). Pp. 1-29.

Gerlitz C. What counts? Reflections on the multivalence of social media data. Digital Culture \& Society. 2011. 2 (2). Pp. 19-38.

Gicheru C. W. The Challenges Facing Independent Newspapers in Sub-Saharan Africa. University of Oxford's Reuters Institute Fellowship Paper, 2014.

Gillmor Dan. We the media: Grassroots journalism by the people, for the people. Sebastopol, California: O' Reilly, 2006. 
Goldfain K., Van der Merwe N. The role of the political blog: the case of www.commentary.co.za. Communicare. 2006. Pp. 103-124.

Harrison T., Barthel B. Wielding new media in Web 2.0: Exploring the history of engagement with the collaborative construction of media products. New Media \& Society. 2009. 11 (1-2). DOI: http://doi.org/10.1177/1461444808099580.

Heinonen A. The journalists' relationships with users: New dimensions to conventional roles. Participatory Journalism / Singer J. et al. (Eds.). Chichester: Wiley-Blackwell, 2011. DOI: https:/ /doi.org/10.1002/9781444340747.ch3.

Hermida A. Social journalism: exploring how social media is shaping journalism. The handbook of global online journalism / Siapera E., Veglis A. (Eds.). West. Sussex: Wiley-Blackwell, 2012. Pp. 309-328. DOI: https://doi.org/10.1002/9781118313978. ch17.

Hermida A. Twittering the news. Journalism Practice. 2011. 4(3). Pp. 297-308. DOI: https://doi.org/10.1080/17512781003640703.

Hess K. Breaking Boundaries. Digital Journalism. 2013. 1(1). Pp. 48-63. DOI: http://doi.org/10.1080/21670811.2012.714933.

Holcomb J. et al. How mainstream media outlets use Twitter. Pew Research Canter's Project for excellence in Journalism, 2011.

Howard P. N., Hussain M. M. Democracy's Fourth Wave? Digital Media and the Arab Spring. New York: Oxford University press, 2013.

Hultin J., Skog D. The digitalized newspaper organization: An identity crisis in the midst of the challenges of being early adopters of converged digital services. 2011. URL: www.diva-potal.org.

International Telecommunication Union (ITU). Internet Users. Statistics and Indicators, 2001.

Johnston J., Forde S. The silent partner: News agencies and 21st Century News. International Journal of Communication. 2011. $5(1)$.

Joseph J. The EU in the Horn of Africa: Building Resilience as a Distant Form of Governance. Journal of Common Market Studies. 2013. 1-17. DOI: https://doi.org/10.1111/jcms.12085.

Kaid L. Changing and staying the same: communication in campaign 2008. Journalism Studies. 2009. 10(3). Pp. 417-423. DOI: https://doi.org/10.1080/14616700902812728.

Kaplan A., Haenlein M. Users of the world, unite! The challenges and opportunities of social media. Business Horizons. 2010. 53(1). Pp. 59-68. DOI: https://doi.org/10.1016/j.bushor.2009.09.003.

Konieczna, M. \& Robinson, S. (2014). Emerging news non-profits: A case study for rebuilding community trust? Journalism. 15(8): 968-986. DOI: http://doi.org/10.1177/ 1464884913505997.

Kovac M., Rosenthal M. The elements of journalism: What news people should know and the public should expect. New York: Crown Publishers, 2001.

Kupe T. The Untold 21st Century Story. Rhodes Journalism Review. 2003. (23). Pp. 1-20.

Larkin B. Degraded Images, Distorted Sounds: Nigerian Video and the Infrastructure of Piracy. Public Culture. 2004. 16 (2). Pp. 289-314. DOI: https://doi.org/10.1215/08992363-16-2-289.

Larsson A. O., Moe H. Studying political microblogging: Twitter users in the 2010 Swedish election campaign. New Media \& Society. 2012. 14(5). Pp. 729-747. DOI: https://doi.org/10.1177/ 1461444811422894

Lee-Wright P. Culture Shock: New Media and organisational change in the BBC. New Media, Old News: Journalism and Democracy in the Digital Age / N. Fenton (Ed.). London: Sage, 2010.

Lewis D., Mosse D. Development Brokers and Translators: The Ethnography of Aid and Agencies. Bloomfield, CT: Kumarian Press, 2006.

Lewis S. C., Holton A. E., Coddington M. Reciprocal journalism: A concept of mutual exchange between journalists and audiences. Journalism Practice. 2014. 8(2). Pp. 29-241. DOI: http:/ /doi.org/10.1080/17512786.2013.859840.
Lowrey W. Mapping the Journalism-Blogging Relationship. Journalism. 2006. 7(4). Pp. 477-500. DOI: https://doi.org/10.1177/ 1464884906068363

Matsiola M. New technological tools in contemporary journalism: Study concerning their utilization by the Greek journalists related to the use of the internet as a mass medium. Unpublished $\mathrm{PhD}$ thesis, Department of Journalism and Mass Media, Aristotle University of Thessaloniki, 2008.

Mchakulu J. E. How did we ever manage without them in the past? Journalists' Use of Computers and Mobile Telephones. Paper presented at the Communication Technologies of Empowerment Postgraduate Research Conference, Institute of Communications Studies (ICS), University of Leeds, 18 May. 2007.

McNair B. The Sociology of Journalism. London: Arnold, 1998.

Media and Democracy in Africa / Hydén G., Leslie M., Ogundimu F. F., Hyden G. (Eds.). New Brunswick, NJ: Transaction Publishers, 2002.

Media and Identity in Africa / Njogu K., Middleton J. (Eds.). Edinburgh: Edinburgh University Press, 2009.

Meyer B. Introduction: From Imagined Communities to Aesthetic Formations: Religious Mediations, Sensational Forms and Styles of Binding. Aesthetic Formations: Media, Religion and the Senses / Birgit Meyer (Ed.). New York: Palgrave Macmillan, 2010.

Mishra R. Digital democracy and student politics: Interpretation from Assam university student's council elections. International Journal of Management Humanities and Social Sciences. 2016. 1(1). Pp. 46-54.

Moyo D. Citizen Journalism and the Parallel Market of Information in Zimbabwe's 2008 Election. Journalism Studies. 2009. 10(4). Pp. 551-567. DOI: https://doi.org/10.1080/14616700902797291.

Mudhai F. Researching the impact of ICTs as change catalysts in Africa. Ecquid Novi: South African Journal for Journalism Research. 2004. 25(2). Pp. 313-335.

Mwanjoka O. Final workshop report: Introduction of information and communication technologies in rural areas. 2002. URL: http://www.ics.trieste.it/ documents/hightech/telecom/ activities/wsdec2002/Final\%20Report.pdf.

Newman N., William H. D., Grant B. Social Media in the Changing Ecol-ogy of News: The Fourth and Fifth Estates in Britain. International Journal of Internet Science. 2012. 7(1). Pp. 6-22.

Nwosu I. E. Mobilizing people's support for development: An analysis of public enlightenment campaigns in Africa. Africa Media Review. 1986. 1(1). Pp. 48-65.

O'Sullivan J. Delivering Ireland: Journalism's search for a role online. Gazette. 2005. 67(1). Pp. 45-68.

Obeng-Quaidoo I. A proposal for New Communication Research Methodologies in Africa. Africa Media Review. 1986. 1(1). Pp. 89-98.

Okon G. B. Basic dimensions in mass communication. Lagos, Nigeria: HdX Communications LTD, 2001.

Pavlik J. V. Journalism and new media. New York: Columbia University Press, 2001. URL: http://icankihsan.weebly.com/ uploads/1/8/7/4/18748648/journalismandn ew media.pdf.

Pew Research Centre. The State of the News Media. New York: Project for Excellence in Journalism and Pew Internet and American Life Project, 2010. URL: http://stateofthemedia.org/ 2010/online-summaryessay/.

Picard R. G. Media Firms: Structures, Operations, and Performance. London: Routledge, 2014

Prado P. Mapping citizen journalism and the promise of digital inclusion: A perspective from the Global South. Global Media and Communication. 2017. 13(2). Pp. 1-18.

Quinn S., Quinn-Allan D. The world-wide spread of journalism convergence. Refereed paper presented to the Journalism Education Conference, Griffith University, 29 November - 2 December, School of Communication and Creative Arts Deakin University. 2005. 
Rosen J. AMost Useful Definition of Citizen Journalism. In Wikipedia. 2008.

Saul M., Austen R. A. Viewing African Cinema in the Twenty-first Century: Art Films and the Nollywood Video Revolution. Athens: Ohio University Press, 2010.

Serra S. Citizen Journalism. AIP Scholaris. 2013. 2(1). Pp. 1-16. URL: http://scholaris.vse.cz/index.php/scholaris/article/ download/14/10

Shipley J. W. Aesthetic of the Entrepreneur: Afro-cosmopolitan Rap and Moral Circulation in Accra, Ghana. Anthropological Quarterly. 2009. 82 (3). Pp. 631-68.

Siapera Eugenia, Lambrini Papadopoulou, Fragiskos Archontakis. Post-Crisis Journalism. Journalism Studies. 2014. 16 (3). Pp. 449-465. DOI: 10.1080/1461670X.2014.916479.

Sperlich R. Mediamorphosis of cultural creation and a study of the digital mediamorphosis in rock and electronic music in Austria. A Paper presented at the Media Change and Social Theory Conference in Oxford Session 604-a, September 7, 2006. URL: http://users.auth.gr/baltzis/papers/seminar_04_mediamorphosis.pdf

Spitulnik D. Alternative Small Media and Communicative Spaces. Media and Democracy in Africa / Göran Hydén, Michael Leslie, Folu F. Ogundimu (Eds.). New Brunswick, NJ: Transaction Publishers, 2002

Spyridou L. P. Journalistic content on the web: Studying interactivity in Greek online newspapers. Unpublished PhD thesis, Department of Journalism and Mass Media, Aristotle University of Thessaloniki, 2009.

Suntai D. I., Targema T. S. Social media and democracy in Africa: assessing the 2015 general election experience in Nigeria. Paper presented at the International Conference on Demo- cracy, Dictatorship and Development in Africa. Department of History and International Studies. Ibrahim Badamasi Babangida University, Lappi. 2-5 August. 2015.

Tapscott D., Williams A. D. Wikinomics: How Mass Collaboration Changes Everything. New York: Penguin, 2006.

Tomno C. J. Journalism and social media. Centre for International Media Ethics (CIME): Nairobi, Kenya, 2012.

Udeze S. E. Media law and ethics. Enugu, Nigeria: Rhyce Kerex Publishers Limited, 2012.

Ugwuanyi C., Gever V. C., Olijo I. Social media as tools for political views expressed in the visuals Shared among social media users. Library Philosophy and Practice. 2019. 1-19.

Uwakwe O. Media writing and reporting: who, what, when, where and how (3rd ed.). Enugu, Nigeria: Cecta Books, 2012.

Veglis A. Journalism and cross media publishing: the case of Greece. Handbook of online journalism / Siapera E., Veglis A. (Eds.). The Wiley-Blackwell, 2012.

Verclas K., Mechael P. A Mobile Voice: The Use of Mobile Phones in Citizen Media. Washington: United States Agency for International Development. 2008. URL: http://www.usaid.gov/ about_usaid/hrd/A_Mobile_Voice.pdf.

Vodafone. Africa, the impact of mobile phones: Moving the debate forward. Vodafone Policy Papers Series No. 2. Vodafone Group. 2005.

Wasserman H. Popular Media, Democracy and Development in Africa. London: Routledge, 2011.

Wogu Joseph, Ezeah Greg, Gever Verlumun Celestine, Ugwuanyi John Chidi. Politicking in the digital age: engagement in computermediated political communication and citizens' perception of political parties, politicians and the government. Library Philosophy and Practice. 2019. 1-20.

Йосиф Олучукву Вогу, кафедра масової комунікаиії, Університет Нігерії (м. Ншекка, Нігерія) e-mail: Joseph.Wogu@unn.edu.ng, ORCID 0000-0002-2384-1510

\section{УРАХУВАННЯ НЕПОЧУТИХ ГОЛОСІВ ТА ВІДДАЛЕНИХ РАЙОНІВ У ЦИФРОВУ ЕПОХУ: ОЦІНКА РЕІНЖИНІРИНГУ ЗБОРУ НОВИН В АФРИЦІ}

Історично склалося так, що Африка відстає в засвоєнні технологій, у тому числі - в галузі мас-медіа. І хоч Африка є другим (після Азії) за територією континентом, понад $60 \%$ її населення живе в районах, віддаленість і небезпечність яких не дозволяють журналістам і ЗМІ повноцінно висвітлювати їх соціально-економічне, культурне і політичне життя. До переліку проблем слід додати нестачу кваліфікованих кадрів, надмірні витрати, внутрішні конфлікти, неспроможність медіа-індустрії навчати та/або запрошувати достатню кількість журналістів, байдужість урядової й муніципальної політики в галузі масових комунікацій. Частково вказані проблеми вирішуються за рахунок ініціатив місцевого населення, представники якого викладають новинний контент в Інтернет-мережах, але вони не можуть принципово зняти питання. Дана стаття присвячена вивченню динаміки надходження новин в епоху технологічно орієнтованого Інтернету для виявлення існуючих обмежень в африканських внутрішніх районах. Географічно дослідження орієнтоване на африканські сільські громади. В статті розглядаються шляхи набуття й використання нових інформаційних технологій, зокрема, мобільних телефонів 3 інтернет-можливостями, для генерування і розповсюдження новин 3 африканських внутрішніх районів. Виявлено фактори, що заважають такій практиці і шляхи їх усунення. Хронологічно дослідження охоплює XXI століття, тобто від 2000 року до тепер. Саме в цей період відбувалося масове проникнення Інтернету у внутрішні райони та використання його як основного засобу комунікації. Досліджуючи дігіталізацію комунікації в сільській Африці, де більшість населення живе поза регулярним або формальним зв'язком з органами і каналами управління, відірване від зовнішнього світу, автор визначає масштаб проблем, з якими стикається модернізація. Розкриваються технології підходів до збирання новин у сільській Африці, залучення її до участі в електронному управлінні, глобальному діалозі й дискусіях з усіх аспектів людського розвитку, прав і політики. Оцінюються життєздатні альтернативи інтернет-посередництва в галузі журналістики.

Ключові слова: збір новин; внутрішні райони; Африка; інтернет-технології; глобалізація; розвиток.

(c) Joseph Oluchukwu Wogu

Надійшла до редакції: 08.11.2019

Прийнята до друку: 27.11.2019

СХІД №̄ 6 (164) листопад-грудень 2019 р.

ISSN 1728-9343 (Print) ISSN 2411-3093 (Online) 